\title{
MEWUJUDKAN MASYARAKAT BERKARAKTER PEDULI LINGKUNGAN MELALUI PROGRAM ADIWIYATA
}

\author{
Mirza Desfandi \\ Universitas Syiah Kuala Banda Aceh \\ Email:mirza_des@yahoo.com \\ Naskah diterima : 27 April 2015, direvisi : 7 Mei 2015, disetujui : 25 Mei 2015
}

\begin{abstract}
This article aims to provide an effort to educate and inform the public about environmental issues become more critical. Develop community character can effectively care for the environment is possible through environmental education in schools. As a place of learning, the school has a special role to play; schools can help students to understand the impact of buman behavior on Earth. Adiwiyata program implemented in order to realize the school community who are responsible for the protection and management of the environment through good school governance to support sustainable development. Adiwiyata program combines learning and action, so as to provide an effective method to change behavior. Adiwiyata school is expected to be agents of change for the people in the neighborhood around the school. Schools should be a model in creating a healthy and comfortable environment as well as being a model in creating a school community that cares and cultured environment. School community then expected to be an example and transmit characters care about the environment to the public.
\end{abstract}

Keywords: character concerned about the environment; Adiwiyata Program

\begin{abstract}
Abstrak
Artikel ini bertujuan memberikan upaya untuk mendidik dan memberi informasi kepada masyarakat mengenai masalah lingkungan yang semakin kritis. Mengembangkan masyarakat berkarakter peduli lingkungan dimungkinkan dapat efektif melalui pendidikan lingkungan di sekolah. Sebagai tempat belajar, sekolah memiliki peran khusus untuk bermain; sekolah dapat membantu siswa untuk memahami dampak perilaku manusia di bumi ini. Program Adiwiyata dilaksanakan guna mewujudkan warga sekolah yang bertanggung jawab dalam upaya perlindungan dan pengelolaan lingkungan hidup melalui tata kelola sekolah yang baik untuk mendukung pembangunan berkelanjutan. Program Adiwiyata menggabungkan pembelajaran dan tindakan, sehingga memberikan metode yang efektif untuk mengubah perilaku. Sekolah Adiwiyata diharapkan dapat menjadi agen perubahan bagi masyarakat di lingkungan sekitar sekolah. Sekolah harus menjadi model dalam mewujudkan lingkungan yang sehat dan nyaman serta menjadi model dalam mewujudkan warga sekolah yang peduli dan berbudaya lingkungan. Warga sekolah selanjutnya diharapkan dapat menjadi contoh dan menularkan karakter peduli lingkungan kepada masyarakat.
\end{abstract}

Kata kunci: karakter peduli lingkungan; Program Adiwiyata

Pengutipan: Desfandi, M. (2015). Mewujudkan Masyarakat Berkarakter Peduli Lingkungan Melalui Program Adiwiyata. SOSIO DIDAKTIKA: Social Science Education Journal, 2(1), 2015, 31-37. doi:10.15408/ sd.v2i1.1661

Permalink/DOI: http://dx.doi.org/10.15408/sd.v2i1.1661 


\section{A. Pendahuluan}

Pembangunan yang dilaksanakan saat ini di berbagai negara mengalami perkembangan pesat pada berbagai sektor. Namun, masyarakat dunia juga menghadapi berbagai bencana/ permasalahan lingkungan, seperti banjir, tanah longsor, kekeringan dan kebakaran hutan yang menimbulkan kerugian materi maupun korban manusia. Masyarakat internasional saat ini telah menyepakati pentingnya menjaga bumi dari pencemaran dan kerusakan, misalnya melalui pembangunan berkelanjutan. Pembangunan berkelanjutan telah menjadi komitmen dan tanggung jawab bersama masyarakat dunia untuk menyelamatkan bumi dari kerusakan dan kehancuran akibat pembangunan yang tidak memperhatikan kelestarian lingkungan. Pembangunan berkelanjutan berusaha untuk memahami interaksi antara alam dan masyarakat dalam rangka untuk mempromosikan transisi menuju keberlanjutan. Inti dari pembangunan berkelanjutan adalah memenuhi kebutuhan dasar manusia sambil menjaga sistem pendukung kehidupan planet bumi. ${ }^{1}$

Dalam rangka menghadapi tantangan lingkungan di bumi, ada kebutuhan untuk mendidik dan memberi informasi kepada masyarakat mengenai permasalahan lingkungan. Salah satu komitmen masyarakat dan pemerintah internasional dalam menjaga bumi dari pencemaran dan kerusakan adalah melalui pelaksanaan Pendidikan Lingkungan Hidup (Environment Education), yang merupakan kunci untuk mempersiapkan masyarakat dengan pengetahuan, keahlian, nilai dan sikap peduli lingkungan sehingga dapat berpartisipasi aktif dalam memecahkan masalah lingkungan. ${ }^{2}$ Pendidikan Lingkungan Hidup menurut konvensi UNESCO di Tbilisi (1997) merupakan suatu proses yang bertujuan untuk menciptakan suatu masyarakat dunia yang memiliki kepedulian terhadap lingkungan dan peduli terhadap masalah-masalah yang terkait di dalamnya serta memiliki pengetahuan, motivasi, komitmen, dan keterampilan untuk bekerja, baik secara perorangan maupun kolektif dalam mencari alternatif atau memberi solusi

\footnotetext{
Salome Hallfreðsdóttir. Eco Schools - Are They Really Better? (Thesis: $\begin{array}{cc}1 & \text { Salome Hallfreðsdóttir. Eco Schools } \\ \text { Lund University. Lund: Tidak diterbitkan, 2011). }\end{array}$

2 Sibel Ozsoy, Hamide Ertepinar, dan Necdet Saglam, "Can Eco-Schools Improve Elementary School Students' Environmental Literacy Levels?” dalam Jurnal: AsiaPacific Forum on Science Learning and Teaching, Vol. 13 Issue 2/December 2012
}

terhadap permasalahan lingkungan hidup yang ada sekarang dan untuk menghindari timbulnya masalah-masalah lingkungan hidup baru. ${ }^{3}$

\section{Proses pembelajaran Pendidikan} Lingkungan Hidup yang dilaksanakan hendaknya merupakan suatuproses mengorganisasinilaidan memperjelas konsep-konsep untuk membina keterampilan dan sikap yang diperlukan untuk memahami dan menghargai antar hubungan manusia, kebudayaan, dan lingkungan fisiknya. Pengetahuan dan kesadaran tentang keberadaan dan ruang lingkup masalah lingkungan adalah penting karena dapat membangkitkan kepedulian dan perhatian terhadap lingkungan. Penekanannya harus pada (i) pengetahuan tentang penyebab, (ii) pengetahuan tentang efek, dan (iii) pengetahuan tentang strategi untuk berubah, ketika menghadapi masalah lingkungan. ${ }^{4}$

Mengembangkan masyarakat berkarakter peduli lingkungan dimungkinkan dapat efektif melalui pendidikan lingkungan di sekolah. Sebagai tempat belajar, sekolah memiliki peran khusus untuk bermain; sekolah dapat membantu siswa untuk memahami dampak perilaku manusia di bumi ini, dan menjadi tempat di mana hidup yang berkelanjutan. ${ }^{5}$ Akan tetapi berbagai masalah lingkungan yang semakin tak terkendali menunjukkan bahwa Pendidikan Lingkungan Hidup belum berhasil membentuk karakter manusia yang peduli terhadap lingkungan. Kegagalan tersebut terjadi karena adanya sejumlah kelemahan dalam Pendidikan Lingkungan Hidup. Kegagalan tersebut tidak lepas dari hal-hal berikut: ${ }^{6}$

1. Masih rendahnya partisipasi masyarakat untuk berperan dalam pendidikan lingkungan hidup, karena kurangnya pemahaman terhadap permasalahan pendidikan lingkungan, rendahnya tingkat kemampuan atau keterampilan, dan rendahnya komitmen masyarakat dalam menyelesaikan permasalahan tersebut.

2. Pemahaman pelaku pendidikan terhadap

\footnotetext{
3 UNESCO. The UN Decade of Education for Sustainable Development. The First Two Years. (Paris: UNESCO, 2007).

4 F. Mogensen \& M. Mayer (Eds.), Eco-School trends and divergences: $A$ comparative study of Eco School development process in 13 countries, (Vienna: Austrian Federal Ministry of Education, Science and Culture, Dept. Environmental Education Affairs, 2005).

5 Op. cit., Sibel Ozsoy, Hamide Ertepinar, dan Necdet Saglam.

6 Sungkowo, Konsep Pendidikan Lingkungan Hidup Pada Jalur Pendidikan Dasar dan Menengah, (Jakarta: Dikdasmen, 2005).
} 
pendidikan lingkungan yang masih terbatas. Dalam jalur pendidikan formal, masih ada anggapan bahwa pendidikan lingkungan hidup tidak begitu penting.

3. Materi dan metode pelaksanaan pendidikan lingkungan hidup dirasakan belum memadai, dan kurang aplikatif, sehingga pemahaman kelompok sasaran mengenai pelestarian lingkungan hidup menjadi tidak utuh.

4. Sarana dan prasarana dalam pendidikan lingkungan hidup belum mendapat perhatian yang cukup. Sarana dan prasarana untuk pendidikan lingkungan hidup sering kali disalahartikan sebagai sarana fisik yang berteknologi tinggi sehingga menjadi faktor penghambat tumbuhnya motivasi dalam pelaksanaan Pendidikan Lingkungan Hidup.

5. Kurangnya kemampuan pemerintah untuk mengalokasikan dan meningkatkan anggaran pendidikan lingkungan, sehingga pelaksanaan Pendidikan Lingkungan Hidup di berbagai instansi tidak maksimal.

6. Lemahnya koordinasi antar instansi terkait dan para pelaku pendidikan menyebabkan kurang berkembangnya Pendidikan Lingkungan Hidup. Hal ini terlihat pada gerakan Pendidikan Lingkungan Hidup (formal dan nonformal/informal) yang masih bersifat sporadis, tidak sinergis dan saling tumpang tindih.

Salah satu upaya untuk mengatasi kelemahan dalam Pendidikan Lingkungan Hidupini, sekolah harus memberikan praktek pembelajaran yang efektif untuk mengembangkan perilaku bertanggung jawab terhadap lingkungan dan lingkungan belajar yang diperlukan harus memberikan siswa kesempatan untuk belajar di luar kelas, mengamati alam, berlatih dan menguji isu-isu belajar tentang lingkungan. Berdasarkan hal ini, pada bagian selanjutnya dari tulisan ini penulis mencoba untuk menguraikan salah satu upaya yang komprehensif dalam menanamkan literasi lingkungan pada siswa guna mewujudkan masyarakat berkarakter peduli lingkungan, yaitu melalui program Adiwiyata.

\section{B. Pembahasan}

Satu hubungan yang sangat dinamis antara manusia dan lingkungannya, dapat dilihat dari bagaimana cara manusia hidup bersama, berdampingan dengan semua komponen di sekitarnya. Kemampuan yang dimiliki setiap individu untuk berperilaku baik dalam kesehariannya dengan menggunakan pemahamannya terhadap kondisi lingkungan itulah yang disebut dengan literasi lingkungan atau environment literacy. ${ }^{7}$ Literasi lingkungan bukanlah sebuah disiplin ilmu baru atau bahkan sebuah konsep baru dalam mengkaji hubungan manusia terhadap lingkungannya. Ini merupakan pemikiran yang sederhana dan berangkat dari fisis determinisme, fisis possibilisme atau bahkan pandangan antroposentrisme.

Fisis determinisme merupakan pandangan bahwa alam telah menyediakan semua yang dibutuhkan manusia untuk hidup dan manusia berusaha untuk sejalan dengan kondisi lingkungan yang ada. Dalam hal ini, manusia tidak mempunyai banyak alternatif untuk menentukan perannya terhadap lingkungan di mana dia tinggal. Lain halnya dengan fisis possibilisme, manusia mempunyai begitu banyak kemungkinan, begitu banyak alternatif untuk meminimalisir kekurangan dari kondisi lingkungan yang ada. ${ }^{8}$ Dengan kata lain, manusia bisa berpikir dan berupaya keras bagaimana mengatasi keterbatasan yang alam sediakan. Literasi lingkungan dapat berupa halhal sederhana, misalnya:

1. Menyediakan 25\% ruang terbuka bervegetasi di rumah. Dengan adanya lahan terbuka bervegetasi, berarti telah membiarkan air hujan bisa masuk meresap ke dalam tanah, telah memberikan kelangsungan dalam siklus gas terutama oksigen dan karbon dioksida dengan baik.

2. Menyediakan fentilasi yang cukup. Dengan adanya fentilasi, berarti selain terjadi siklus gas terutama oksigen dan karbon dioksida dengan baik. Fentilasi berguna juga untuk mencegah rumah menjadi tempat yang kumuh dan lembab.

\footnotetext{
7 Op. cit., Salome Hallfreðsdóttir.

A. Purwadi, EFSD in Indonesia at a Glance in EFSD Currents: Changing Perspective from The Asia-Facific, (Bangkok: UNESCO, 2009).
} 
3. Membiarkan cahaya matahari masuk di pagi dan siang hari. Cahaya matahari berfungsi untuk membunuh bakteri jahat di rumah.

4. Mendirikan rumah di tempat yang landai. Dengan demikian penghuni rumah bisa terhindar dari resiko longsor jika terjadi hujan lebat.

Sejak kelahirannya, masalah literasi lingkungan telah menarik perhatian banyak peneliti pendidikan dan ilmuwan lingkungan. Meskipun istilah ini telah banyak didiskusikan, tetapi tidak ada definisi yang disepakati secara umum. Definisi awal literasi lingkungan dikemukakan oleh Roth (1968) yang mendefinisikan orang yang melek lingkungan sebagai seseorang yang memiliki keterampilan dasar, pemahaman dan perasaan mengenai hubungan manusia-lingkungan. Kemudian Roth menambahkan bahwa orang melek lingkungan memahami keterkaitan antara sistem alam dan sosial, kesatuan manusia dengan alam, bagaimana teknologi mempengaruhi pengambilan keputusan masalah lingkungan dan pembelajaran tentang lingkungan adalah suatu usaha seumur hidup. ${ }^{9}$

Meskipun ada perbedaan definisi dan komponen literasi lingkungan, solusi untuk mengatasi masalah lingkungan adalah dengan mengembangkan masyarakat yang melek lingkungan, berperilaku dengan cara yang lebih bertanggung jawab terhadap lingkungan. Sebuah perilaku dianggap yang bertanggung jawab terhadap lingkungan ketika tindakan individu atau kelompok menganjurkan penggunaan secara berkelanjutan atau efisien terhadap sumber daya alam. Salah satu wujud/ bentuk masyarakat yang memiliki literasi lingkungan adalah masyarakat yang berkarakter peduli lingkungan. Karakter merupakan nilainilai perilaku manusia yang berhubungan dengan Tuhan Yang Maha Esa, diri sendiri, sesama manusia, lingkungan, dan kebangsaan yang terwujud dalam pikiran, sikap, perasaan, perkataan, dan perbuatan berdasarkan normanorma agama, hukum, tata krama, budaya, dan adat istiadat.

Untuk membangun masyarakat berkarakter peduli lingkungan, salah satunya melalui

\footnotetext{
9 Op. cit., Sibel Ozsoy, Hamide Ertepinar, dan Necdet Saglam.
}

bidang pendidikan. Seperti kita ketahui, pendidikan merupakan salah satu aspek yang dapat mempengaruhi dunia masa depan dan merupakan cara yang paling efektif dalam membentuk masyarakat yang memiliki kemampuan untuk menghadapi tantangan di masa depan. Pendidikan menjadi dasar bagi tindakan dan penting untuk dapat meningkatkan kapasitas masyarakat, hal ini menekankan bahwa baik pendidikan formal dan non formal sangat diperlukan untuk mengubah sikap masyarakat. Selama ini pendidikan di seluruh dunia lebih mengutamakan literasi dasar (matematika, fisika, kimia, biologi teknologi dan lainlain) daripada literasi lingkungan (konservasi sumberdaya, multikulturalisme, pembangunan berkelanjutan, demokrasi, kepekaan sosial, budi pekerti dan lain-lain)..$^{10}$ Karena itu perlu dilakukan reorientasi pendidikan, yang berarti diintegrasikannya literasi lingkungan dengan literasi dasar.

Reorientasi pendidikan telah menjadi istilah yang sangat penting bagi pengelola sekolah dan pendidik pada semua tingkatan pendidikan untuk memahami perubahan yang dibutuhkan. Reorientasi yang penting adalah lebih banyak dimasukannya prinsip-prinsip, keterampilan, perspektif dan nilai-niai yang berkaitan dengan pembangunan berkelanjutan dalam pendidikan, yang tepat dan relevan dengan satuan pendidikan. Reorientasi pendidikan juga dipandang sebagai upaya mengembangkan pendidikan/ pembelajaran yang membangkitkan pengetahuan, keterampilan, perspektif, dan nilai yang akan membimbing dan memotivasi manusia menuju kehidupan yang berkelanjutan, berpartisipasi dalam masyarakat yang demokratis, dan hidup secara berkelanjutan.

Salah satu bentuk implementasi pendidikan untuk pembangunan berkelanjutan berbasis PendidikanLingkunganHidupyangdilaksanakan secara terprogram di sekolah adalah program Eco School. Program Eco School merupakan program internasional yang bertujuan untuk meningkatkan literasi lingkungan pada siswa. Program Eco School dikembangkan oleh Foundation of Enviromental Education (FEE) pada tahun 1994, yang dikembangkan atas dasar kebutuhan untuk melibatkan kaum muda dalam

\footnotetext{
10 Op. cit., UNESCO. The UN Decade of Education for Sustainable Development. The First Two Years.
} 
mencari solusi terhadap tantangan lingkungan hidup dan pembangunan berkelanjutan di tingkat lokal. ${ }^{11}$ Munculnya Eco School, berangkat dari keprihatinan bersama untuk memperbaiki kualitas lingkungan. Cukup banyak strategi yang telah ditempuh untuk memperbaiki kualitas lingkungan, mulai dari penyuluhan, penataran, bimbingan, proyek percontohan dan perbaikan komponen yang menyebabkan rusaknya lingkungan seperti reboisasi, kali bersih, jumat bersih dan gerakan sadar kebersihan. Programprogram tersebut sudah lama dilakukan tetapi tidak memberikan hasil yang signifikan, karena yang dirasakan hanya kerusakan yang terus berlanjut dan semakin parah. ${ }^{12}$

Program Eco School dikembangkan sebagai sarana penyampaian komitmen Agenda 21. Fokus Agenda 21 pada program Eco School adalah mempromosikan tindakan lokal yang bertujuan untuk memecahkan masalah lingkungan global melalui pendidikan. Program Eco Schoolmenawarkan kesempatan bagi sekolah untuk menghubungkan dengan komunitas mereka dan bekerja sama untuk memecahkan dan mencegah masalah lingkungan di tingkat lokal. Tujuan utama dari program Eco School adalah mempersiapkan anak-anak untuk hidup berkelanjutan dan untuk menunjukkan bahwa hidup yang berkelanjutan adalah bagaimana menemukan solusi terhadap masalah yang kita hadapi dan meningkatkan kualitas hidup masyarakat tanpa merusak lingkungan. ${ }^{13}$

Program Eco School menggabungkan pembelajaran dan tindakan, sehingga memberikan metode yang efektif untuk mengubah perilaku. Munculnya program Eco School telah menarik perhatian di seluruh dunia. Program Eco School merupakan program yang demokratis dan partisipatif serta memberikan kesempatan kepada orang-orang muda untuk terlibat di sekolah dan di masyarakat untuk mempromosikan keberlanjutan sebagai warga negara aktif. Negara-negara yang menerapkan program Eco School dapat menyesuaikan program untuk memenuhi kebutuhan dan prioritas mereka dalam konteks wilayah

11 Foundation of Environment Education, Eco-Schools Programme, dalam http://www.eco-schools.org/brochure_eco.pdf, 2009 Diakses pada [11 Desember 2014]

12 Darsiharjo, "Eco-School" Sebagai Media Pedidikan Lingkungan Di Sekolah, Makalah disampaikan pada Seminar Nasional "Peran Pendidikan di Persekolahan dalam Mempersiapkan Generasi Peduli Lingkungan” di Auditorium JICA FPMIPA UPI Bandung pada tanggal 1 Desember 2005.

13 Op. cit., Sibel Ozsoy, Hamide Ertepinar, dan Necdet Saglam. mereka (lokal). Program Eco School bertujuan pada penghargaan lingkungan internasional bergengsi yaitu Green Flag. Penghargaan ini diberikan sebagai pengakuan bahwa sekolah berkomitmen untuk standar tertinggi dalam pendidikan dan pengelolaan lingkungan. ${ }^{14}$

Program Eco School memilki fokus yang kuat pada masalah-masalah sumber daya, energi dan limbah sebagai bidang utama tindakan. ${ }^{15}$ Meskipun program ini dikoordinasikan melalui kerangka kerja umum di tingkat internasional, negara-negara anggota yang melaksanakan program Eco School memiliki fleksibilitas dalam menyesuaikan program dengan kebutuhan mereka. Umumnya sekolah yang berpartisipasi menerapkan proses tujuh langkah untuk menuju sertifikasi Green Flag, meskipun variasi ada dalam isi dan fokus dari langkah-langkah. Umumnya Langkah-langkah yang dilakukan adalah untuk: ${ }^{16}$

1. Memperbaiki lingkungan sekolah,

2. Mengurangi sampah dan limbah,

3. Mengurangi penggunaan energi dan air,

4. Menemukan cara-cara yang efisien perjalanan ke dan dari sekolah,

5. Mempromosikan gaya hidup sehat,

6. Mendorong kewarganegaraan aktif,

7. Membangun kemitraan yang kuat dengan berbagai kelompok masyarakat.

Di Indonesia, dalam upaya mempercepat pengembangan Pendidikan Lingkungan Hidup khususnya jalur pendidikan formal pada jenjang pendidikan dasar dan menengah, maka pada tanggal 21 Februari 2006 Kementerian Lingkungan Hidup dan Kementerian Pendidikan dan Kebudayaan telah mencanangkan Program Adiwiyata, dengan tujuan mendorong dan membentuk sekolah Peduli dan Berbudaya Lingkungan yang mampu berpartisipasi dan melaksanakan upaya pelestarian lingkungan dan pembangunan berkelanjutan bagi kepentingan generasi sekarang maupun yang akan datang. Adiwiyata mempunyai pengertian atau makna sebagai tempat yang baik dan ideal di mana dapat diperoleh segala ilmu pengetahuan dan berbagai norma serta etika yang dapat menjadi

14 Yu Ping, Global Tbinking, Local Action: A Case Study of the Green School Programme in Cbina. Thesis: Lund University, (Lund: Tidak diterbitkan, 2003).

15 Op. cit., Salome Hallfreðsdóttir.

16 Carly R Ackley, Leadership in Green Schools: School Principals as Agents of Social Responsibility, Dissertasi: The Pennsylvania State University, (Pennsylvania: Tidak diterbitkan, 2009). 
dasar manusia menuju terciptanya kesejahteraan hidup kita dan menuju kepada cita-cita pembangunan berkelanjutan. ${ }^{17}$

Program Adiwiyata dilaksanakan guna mewujudkan warga sekolah yang bertanggung jawab dalam upaya perlindungan dan pengelolaan lingkungan hidup melalui tata kelola sekolah yang baik untuk mendukung pembangunan berkelanjutan. Kegiatan yang dilakukan misalnya pengolahan limbah, pramuka Saka Taruna Bumi, penanggulangan banjir, kantin dan sekolah sehat dan sebagainya. ${ }^{18}$ Dengan melaksanakan program Adiwiyata akan menciptakan warga sekolah, khususnya peserta didik yang peduli dan berbudaya lingkungan, sekaligus mendukung dan mewujudkan sumberdaya manusia yang memiliki karakter bangsa terhadap perkembangan ekonomi, sosial, dan lingkungannya dalam mencapai pembangunan berkelanjutan di daerah. Pelaksanaan Program Adiwiyata diletakkan pada dua prinsip dasar berikut ini: ${ }^{19}$

1. Partisipatif: Komunitas sekolah terlibat dalam manajemen sekolah yang meliputi keseluruhan proses perencanaan, pelaksanaan dan evaluasi sesuai tanggung jawab dan peran.

2. Berkelanjutan: Seluruh kegiatan harus dilakukan secara terencana dan terus menerus secara komprehensif.

Melalui program Adiwiyata diharapkan setiap warga sekolah ikut terlibat dalam kegiatan sekolah menuju lingkungan yang sehat dan menghindari dampak lingkungan yang negatif. Program Adiwiyata dikembangkan berdasarkan norma-norma dalam perikehidupan yang antara lain meliputi: kebersamaan, keterbukaan, kesetaraan, kejujuran, keadilan, dan kelestarian fungsi lingkungan hidup dan sumber daya alam. ${ }^{20}$ Sangat banyak manfaat yang diperoleh sekolah maupun warga sekolah dengan mengikuti program Adiwiyata. Setidaknya ada 5 manfaat mengikuti Program Adiwiyata, yaitu: ${ }^{21}$

1. Mendukung percepatan pencapaian 8 17 Op. cit., Sungkowo.

18 Santa, Saatnya Reorientasi Pendidikan Menuju EFSD Digalakean dalam http://vedca.org/artikel 2012 Diakses pada [11 Desember 2014].

19 Op. cit., Sungkowo.

20 Ellen Landriany, "Implementasi Kebijakan Adiwiyata Dalam Upaya Mewujudkan Pendidikan Lingkungan Hidup di SMA Kota Malang" dalam Jurnal Kebijakan dan Pengembangan Pendidikan Volume 2, Nomor 1, Januari 2014; hal. 82-88.

21 Op. cit., Sungkowo.
Standar Nasional Pendidikan (standar isi, proses, kompetensi lulusan, pendidik dan tenaga kependidikan, sarana dan prasarana, pengelolaan pembiayaan, dan penilaian) sebagaimana diatur dalam PP No. 19 tahun 2006 tentang Standar Nasional Pendidikan.

2. Meningkatkan efisiensi penggunaan dana operasional sekolah melalui penghematan dan pengurangan konsumsi dari berbagai sumber daya dan energi.

3. Menciptakan kebersamaan warga sekolah dan kondisi belajar mengajar yang lebih nyaman dan kondusif.

4. Menjadi tempat pembelajaran tentang nilai-nilai pemeliharaan dan pengelolaan lingkungan hidup yang baik dan benar bagi warga sekolah dan masyarakat sekitar.

5. Meningkatkan upaya perlindungan dan pengelolaan lingkungan hidup meIalui kegiatan pengendalian pencemaran, pengendalian kerusakan dan pelestarian fungsi lingkungan di sekolah.

Sekolah yang telah melaksanakan kegiatankegiatan dengan baik sesuai dengan program Eco School, akan memperoleh pengharagaan "Sekolah Adiwiyata" dari Kementerian Lingkungan Hidup. Sekolah yang telah melaksanakan Program Adiwiyata selain diharapkan dapat mewujudkan lingkungan sekolah sehat, bersih, indah dan nyaman, sehingga dapat membentuk warga sekolah yang peduli dan berbudaya lingkungan, sekolah Adiwiyata juga diharapkan dapat menjadi agen perubahan bagi masyarakat di sekitar sekolah. Sekolah harus menjadi model bagi masyarakat dalam mewujudkan lingkungan yang sehat, bersih, indah dan nyaman. Sikap peduli dan berbudaya lingkungan dari warga sekolah diharapkan dapat ditularkan/berimbas kepada masyarakat sekitar sekolah, guna mewujudkan masyarakat yang berkarakter peduli lingkungan.

\section{Penutup}

Tujuan program Adiwiyata adalah mendorong dan membentuk sekolah Peduli dan Berbudaya Lingkungan yang mampu berpartisipasi dan melaksanakan upaya pelestarian lingkungan dan pembangunan berkelanjutan bagi kepentingan generasi 
sekarang maupun yang akan datang. Melalui program Adiwiyata diharapkan setiap warga sekolah ikut terlibat dalam kegiatan sekolah menuju lingkungan yang sehat dan menghindari dampak lingkungan yang negatif. Warga sekolah selanjutnya harus dapat menjadi model/contoh bagi masyarakat guna mewujudkan masyarakat yang berkarakter peduli lingkungan. Guna mencapai tujuan program Adiwiyata, diperlukan partisipasi semua pihak, mulai dari pemerintah dari tingkat pusat hingga daerah, seluruh warga sekolah, serta masyarakat, baik orang tua siswa maupun tokoh masyarakat.

\section{Daftar Pustaka}

Darsiharjo. (2005). "Eco-School" Sebagai Media Pedidikan Lingkungan Di Sekolah. Makalah disampaikan pada Seminar Nasional "Peran Pendidikan di Persekolahan dalam Mempersiapkan Generasi Peduli Lingkungan" di Auditorium JICA FPMIPA UPI Bandung pada tanggal 1 Desember 2005.

Foundation of Environment Education. (2009). Eco-Schools Programme. Dalam http:// www.eco-schools.org/brochure_eco. pdf, 2009 Diakses pada [11 Desember 2014].

Kementerian Lingkungan Hidup. (2012). Panduan Adiwiyata. Jakarta: Kementerian Lingkungan Hidup Republik Indonesia.

Landriany, Ellen. (2014). Implementasi Kebijakan Adiwiyata Dalam Upaya Mewrijudkan Pendidikan Lingkungan Hidup di SMA Kota Malang. Jurnal Kebijakan dan Pengembangan Pendidikan Volume 2, Nomor 1, Januari 2014.

Mogensen, F., \& Mayer, M. (Eds.). (2005). Eco-School trends and divergences: $A$ comparative study of Eco School development process in 13 countries. Vienna: Austrian Federal Ministry of Education, Science and Culture, Dept. Environmental Education Affairs.

Ozsoy, Sibel., Ertepinar, Hamide., dan Saglam, Necdet. (2012). Can Eco-Schools Improve Elementary School Students' Environmental Literacy Levels? Jurnal: Asia-Pacific Forum on Science Learning and Teaching, Vol. 13 Issue 2/December 2012.

Purwadi, A. (2009). EFSD in Indonesia at a Glance in EFSD Currents:Changing Perspective from The Asia-Facific. Bangkok: UNESCO.

R. Ackley, Carly. (2009). Leadership in Green Schools: School Principals as Agents of Social Responsibility. Dissertasi: The Pennsylvania State University. Pennsylvania: Tidak diterbitkan.

Salome Hallfreðsdóttir, Salome. (2011). Eco Schools - Are They Really Better? Thesis: Lund University. Lund: Tidak diterbitkan.

Santa. (2012). Saatnya Reorientasi Pendidikan Menuju EFSD Digalakean, dalam http://vedca.org/artikel. Diakses pada [11 Desember 2014].

Sungkowo. (2005). Konsep Pendidikan Lingkungan Hidup Pada Jalur Pendidikan Dasar dan Menengah. Jakarta: Dikdasmen.

UNESCO. (2007). The UN Decade of Education for Sustainable Development. The First Two Years. Paris: UNESCO.

Yu Ping, (2003). Global Thinking, Local Action: A Case Study of the Green School Programme in China. Thesis: Lund University. Lund: Tidak diterbitkan. 